\title{
Multivariate analysis relating milk production, milk composition, and seasons of the year
}

\author{
IONE M.P. HAYGERT-VELHO ${ }^{1}$, GABRIEL M. DA CONCEIÇÃO ${ }^{2}$, LUIZ C. COSMAM ${ }^{3}$, \\ DILETA R.M. ALESSIO ${ }^{4}$, MARCOS BUSANELLO ${ }^{5}$, MICHELI R. SIPPERT ${ }^{6}$, CÁSSIA \\ DAMIANI ${ }^{1}$, ANA PAULA A. ALMEIDA ${ }^{1}$ and JOÃO PEDRO VELHO ${ }^{1}$
}

\author{
${ }^{1}$ Departamento de Zootecnia e Ciências Biológicas, Universidade Federal de Santa Maria, Campus de \\ Palmeira das Missões. Av. Independência, 3751, 98300-000 Palmeira das Missões, RS, Brazil \\ ${ }^{2}$ Departamento de Producción Animal y Pasturas, Facultad de Agronomía, Universidad \\ de la Republica Uruguay, Ruta 3, Km 363, 60000 Paysandú, Uruguay \\ ${ }^{3}$ Escola Estadual Técnica Celeste Gobbato, BR 158, Km 106, 98300-000 Palmeira das Missões, RS, Brazil \\ ${ }^{4}$ Universidade Federal de Santa Maria, Campus de Palmeira das Missões, Av. \\ Independência, 3751, 98300-000 Palmeira das Missões, RS, Brazil \\ ${ }^{5}$ Departamento de Zootecnia, Escola Superior de Agricultura “Luiz de Queiroz", Universidade de \\ São Paulo, Campus Piracicaba, Avenida Pádua Dias, 11, 13418-900 Piracicaba, SP, Brazil \\ ${ }^{6}$ Programa de Pós-Graduação em Zootecnia, Universidade Estadual de Maringá, \\ Av. Colombo, 5790, 87020-900 Maringá, PR, Brazil
}

Manuscript received on April 10, 2018; accepted for publication on June 27, 2018

\begin{abstract}
Our objective was to quantify the relationship between seasons of the year, milk production, and milk composition of a dairy farm based on data for 48 consecutive months, using multivariate statistical analyses. The dataset contained information on productive indexes and milk composition from the bulk tank milk, which was measured from milk samples, collected monthly and used to determine the total dry extract and defatted dry extract, lactose, fat, protein, somatic cell count, and total bacterial count. Seasons of the year and milk production/hectare were also considered. Factor, cluster, and discriminant analysis were used to study the relationships between the above-mentioned variables. A positive relationship was noted between season and total dry extract, defatted dry extract, milk fat, and protein, with higher values being observed in winter and spring. Similarly, a positive relationship was noted between season and milk production/hectare, lactose content, with an increase in milk production and lactose content in winter and spring, which was negatively related to the somatic cell count and total bacterial count. Milk production and composition varied mainly with seasons. Multivariate analyses facilitated a better understanding of the relationship between milk production and composition on this dairy farm.
\end{abstract}

Key words: farm management, milk quality, productivity, somatic cell count, statistics.

\section{INTRODUCTION}

From a physiological standpoint, nutrition for

Correspondence to: Ione Maria Pereira Haygert-Velho

E-mail: ione.h.velho@ufsm.br ruminants should be based on roughage (Van Soest 1994), mainly on pastures, so the animals can express their natural behaviors and maintain desired performance (Von Keyserlingk et al. 2009, Pérez-Prieto and Delagarde 2012, Smid et al. 
2018). However, the quantity and quality of the pastures are dependent on the soil and climatic conditions, species and vegetative cycle of the plants, amount of fertilizer used, seasons of the year, and management of the pastures (Bargo et al. 2002, Dall-Orsoletta et al. 2016, Macdonald et al. 2017, Pérez-Prieto and Delagarde 2013, SainzSánchez et al. 2017, Tambara et al. 2017, Virbat et al. 2017). Nonetheless, the animals have daily nutritional requirements that need to be attended (Fox et al. 2004, Lanzas et al. 2007, Tylutki et al. 2008) to avoid a reduction in consumption and production, as well as changes in milk composition (Fagan et al. 2010, Ganche et al. 2014, Hristov et al. 2005). A viable way to meet daily nutritional requirements and allow cows to graze, so that they can manifest their natural behavior and minimize stress, is through semi-confined systems, providing preserved forages and concentrate to complement the nutrients from fresh forage.

Appropriate formulation of diets enables the variation in the milk produced to be controlled and reduced; for the dairy industry, consistency in the quality of milk is important to maintain quality and satisfy the end consumer (Charlebois and Haratifar 2015, Aryana and Olson 2017). It is accepted that many factors influence the production and composition of milk, and a systematic view of the production chain is necessary from agricultural science professionals, as unilateral models do not correctly represent the dynamics of dairy production. According to Mele et al. (2016), multivariate factor analysis is an important tool in the study of the influence of different production environments and to produce milk and dairy products according to the needs and/or desires of consumers. According to Todde et al. (2016), multivariate statistical analysis represents a valid method to simplify the considerable amount of information available regarding the routines of milk farms. An example is cluster analysis, which allows grouping and discriminating between groups, where the Euclidean distances, a measure of similarity, define that the means of nearer observations are in the same group, while the most distant are in separate groups (Lebart et al. 2000).

Our objective, therefore, was to quantify the relationship between seasons of the year, milk production, and milk composition of a dairy farm, based on data for 48 consecutive months, using multivariate statistical analyses.

\section{MATERIALS AND METHODS}

\section{DATABASE}

The data for the present study were obtained from the Escola Estadual Técnica Celeste Gobbato (EETCG), Palmeira das Missões, Rio Grande do Sul, Brazil. The results were generated in the Dairy Cattle Education Unit (DCEU), as shown in the diagram in Figure 1, which presents the detailed activities developed at DCEU. The productivity indexes required for bio-economics management of the DCEU were stored at the EETCG and it was possible to develop a multivariate analysis of the performance of the herd of Holstein cows from data collected for 48 consecutive months, between January 2009 and December 2012.

The climate of the region is Cfa type, with hot summers and rainfall distributed throughout the year, and an average temperature of $22{ }^{\circ} \mathrm{C}$ in the warmest period (Alvares et al. 2013). Table I presents the average temperatures and precipitation collected through the Automatic Meteorological Station of Palmeira das Missões (Longitude: $53^{\circ}$ 18' 49", Latitude: $27^{\circ}$ 53' 58", Altitude: 639 m). The same table also presents the climatological normal of the municipality between 1961 and 1990 .

\section{HERD MANAGEMENT PRACTICES}

The DCEU has 27 hectares available for management of the herd (heifers, lactating cows, dry cows, and a bull) and also facilities including a management center consisting of a waiting area, 


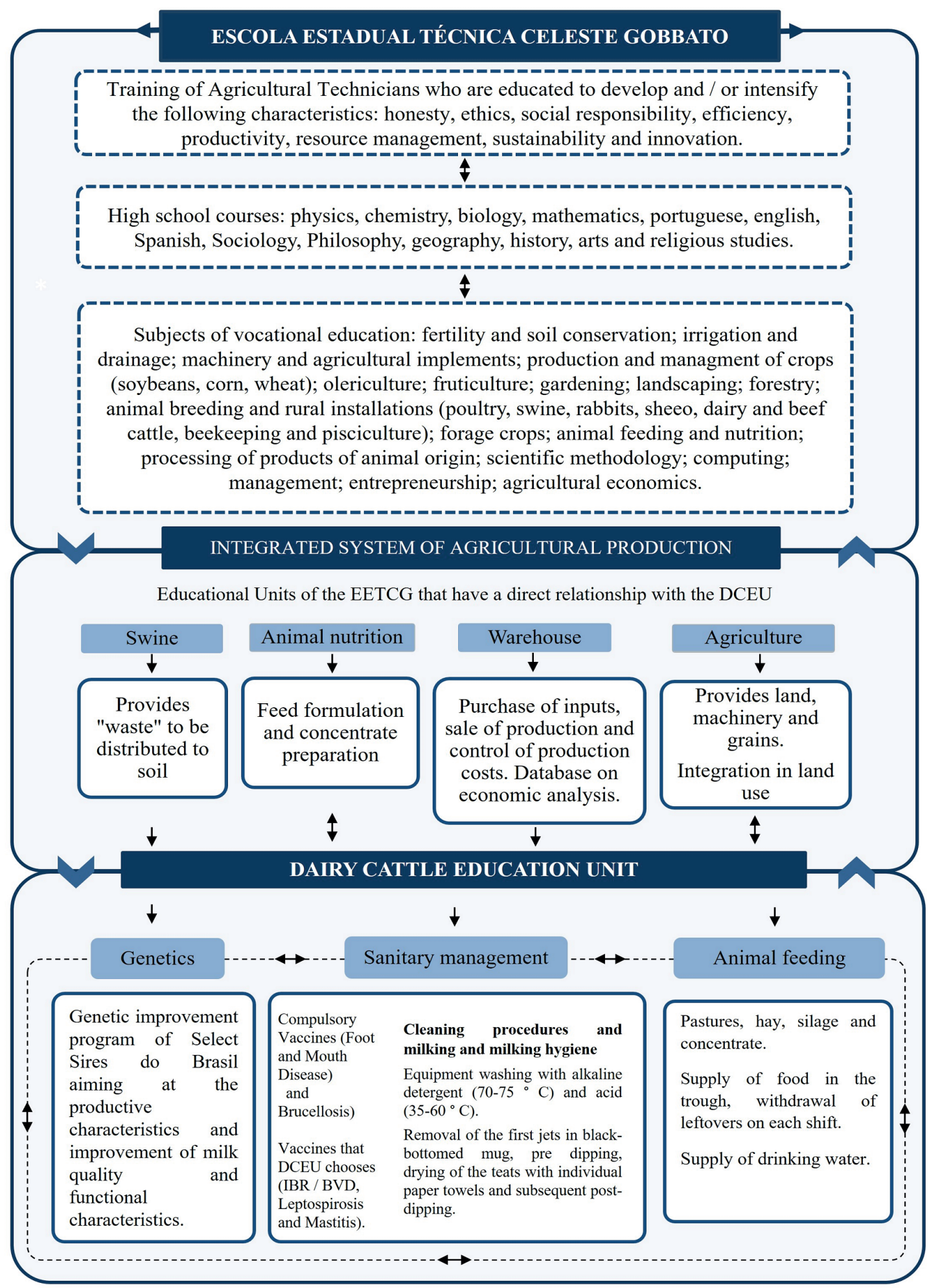

Figure 1 - Summarized graphic representation on the activities of the Escola Estadual Técnica Celeste Gobbato with emphasis on the activities of the Dairy Cattle Education Unit. 
TABLE I

Average temperatures and rainfall in the years 2009, 2010, 2011, and 2012 for Palmeira das Missões, Rio Grande do Sul, Brazil.

\begin{tabular}{|c|c|c|c|c|c|c|c|c|c|c|}
\hline \multirow{3}{*}{ Month } & \multicolumn{8}{|c|}{ Years evaluated } & \multirow{2}{*}{\multicolumn{2}{|c|}{$\begin{array}{c}\text { Climatological } \\
\text { Normal } \\
1961-1990\end{array}$}} \\
\hline & \multicolumn{2}{|c|}{2009} & \multicolumn{2}{|c|}{2010} & \multicolumn{2}{|c|}{2011} & \multicolumn{2}{|c|}{2012} & & \\
\hline & Temp. & Rainfall & Temp. & Rainfall & Temp. & Rainfall & Temp. & Rainfall & Temp. & Rainfall \\
\hline January & 21.3 & 94.4 & 22.7 & 137.8 & 23.4 & 168.2 & 23.2 & 106.0 & 22.9 & 138.5 \\
\hline February & 22.9 & 74.8 & 23.9 & 150 & 22.2 & 247.4 & 24.9 & 89.8 & 22.6 & 137.3 \\
\hline March & 22.4 & 34.0 & 21.7 & 1.8 & 20.9 & 240.2 & 22.8 & 16.6 & 21.1 & 128.4 \\
\hline April & 20.5 & 13.4 & 18.6 & 15.6 & 19.2 & 149.0 & 18.8 & 98.2 & 18.5 & 130.9 \\
\hline May & 17.0 & 213 & 14.5 & 37.2 & 15.0 & 82.2 & 16.7 & 9.2 & 15.6 & 135.3 \\
\hline June & $10.9^{1}$ & $23.4^{1}$ & 14.4 & 120.2 & 12.5 & 260.2 & 13.9 & 141.6 & 13.5 & 123.3 \\
\hline July & 11.3 & 226.0 & 13.2 & 224.4 & 13.4 & 303.8 & 12.6 & 193.2 & 13.3 & 143.0 \\
\hline August & 16.1 & 188.8 & 14.6 & 19.0 & 14.3 & 203.4 & 17.9 & 38.8 & 14.4 & 196.0 \\
\hline September & 15.4 & 357.8 & 16.0 & 198.4 & 16.6 & 1.9 & 17.4 & 115.8 & 16.2 & 189.2 \\
\hline October & 19.0 & 151.2 & 17.2 & 119.2 & 18.9 & 168.8 & 19.2 & 388.0 & 18.1 & 157.6 \\
\hline November & 22.7 & 411.8 & 19.1 & 0.2 & 20.7 & 2.4 & 22.2 & 48.8 & 20.3 & 125.6 \\
\hline December & 22.9 & 168.0 & 21.1 & 248.4 & 22.2 & 1.3 & 23.3 & 159.2 & 22.0 & 142.9 \\
\hline Total & -- & $1,376.8^{1}$ & -- & $1,023.6$ & -- & $1,825.1$ & -- & $1,197.2$ & -- & $1,747.8$ \\
\hline
\end{tabular}

Source: Ministério da Agricultura, Pecuária e Abastecimento (MAPA). Instituto Nacional de Meteorologia (INMET).

${ }^{1}$ In June 2009 during several days the meteorological conditions were not recorded, also affecting the annual rainfall.

milking parlor, cooler room for milk, and a feed shed, as the feed system is semi-confined. The milking parlor is a herringbone type with a pipeline milking system, low line, and it has four sets of closed-circuit and automated cleaning systems.

It should be stressed that the greatest emphasis was placed on the 35 cows that were normally milked during this period, and management of the herd included all the parameters: genetic (acquisition of semen according to the characteristics of each cow), feed and nutrition (annual pastures, production of preserved forages, and concentrate), sanitation (vaccines, medicines, and hygiene products), and milk production. All the daily operations at the DCEU were conducted under the guidance of the relevant teacher and carried out by students of the agricultural technical course. Thus, the students could learn about milk production, ranging from the choice of land (natural resources), artificial insemination, alimentary and nutritional management, and milking of cows, to consideration of the nutritional and functional properties of milk and dairy products for the consumer, according to the approach of Jenkins and McGuire (2006) and Petit (2009). Normative Instructions 51 and 62 of the Ministério da Agricultura, Pecuária e Abastecimento (Brasil 2002, 2011) were also followed.

Management practices undertaken at the DCEU of the EETCG emphasized health, animal welfare, and quality of milk produced, while respecting the use of natural resources. The management practices were registered according to the rules of the Good Practices in the Farm Program (GPFM), according to the indication of the company that markets the milk.

Briefly, GPFM was performed as follows: there was an exclusive pre-delivery area in an easyto-observe location; all animals were identified (via earring) and records were made of the origin of all feed provided to the herd and the preparation and storage of the concentrate. Lactating cows were 
identified by colored collars: blue for dry cows, yellow for colostrum-producing cows, and red for medicated cows. Facilities and equipment were used in conditions that ensured the production of milk within the quality standards required by the dairy company, and in accordance with Brazilian legislation (Normative Instructions 51 and 62) (Brasil 2002, 2011).

For reproductive management, heifers and cows were submitted to a mating program in which morphological characteristics were evaluated so as to select semen that would improve conformational, functional and productive characteristics; the genetic merit of each bull for the production and composition of milk was also evaluated, in accordance with the Select Sires Brazil program.

With respect to feeding and nutritional management, sorghum (Sorghum bicolor) and/or tifton (Cynodon spp.) in the summer, and oats (Avena strigosa) and/or ryegrass (Lolium multiflorum) in the winter were used as fresh forage. Regardless of the season, corn silage (Zea mays) and/or oats silage (Avena sativa), plus concentrate were always supplied and were offered to each lactating cow at an amount compatible with milk production. When seasonal changes in herd management were required, the changes were implemented gradually to avoid possible metabolic disorders. The whole herd had access to drinking water from artesian well drinking fountains, preventing animals from entering sources of surface water (dams, ponds, and rivers).

For sanitary management, the herd was vaccinated against foot-and-mouth disease (May and November) and brucellosis, according to the official calendar of the Inspetoria Veterinária da Secretaria da Agricultura, Pecuária e Irrigação (SEAPI) of Rio Grande do Sul State. Females aged between 3 and 8 months were vaccinated against Brucella abortus (B19) and vaccinated cows were branded on the left side of the face for identification, according to the technical regulations of the
Programa Nacional de Controle e Erradicação da Brucelose e Tuberculose, and females were tested for tuberculosis before commercialization. In addition to the officially recommended vaccines, the herd was also immunized against the following diseases: bovine infectious rhinotracheitis (BIR), bovine viral diarrhea (BVD), leptospirosis (Bioabortogen $\mathrm{H}$ ) and symptomatic carbuncle (Bioclostrigen J5). It is emphasized that such vaccinations are of fundamental prophylactic importance to maintain herd health and avoiding reproductive losses.

For mastitis, lactating cows were vaccinated (Rotatec J5) every 4 months, while heifers and dry cows were vaccinated at 60 and 30 days before calving, respectively. Vaccination against mastitis was established as a form of prevention. This is more cost-effective than the curative treatment for this disease, which generates financial losses in addition to those of milk disposal. Subclinical mastitis also exerts deleterious effects on herd productivity.

Milking was performed twice a day $(5: 30$ a.m. and 4:00 p.m.) using pre- and post-dipping. During every milking session, the first milk jets were collected in a black-bottomed or screened can to monitor for possible clinical mastitis. Every 15 days, the California Mastitis Test (CMT) was performed to monitor the health of the mammary glands and for diagnosis of possible subclinical mastitis.

Immediately following each milking shift, the milking machine was prewashed with water at a temperature of $40^{\circ} \mathrm{C}$. After the prewash, a solution of chlorinated alkaline detergent $(\mathrm{pH}>11)$ was used, with a water temperature of $70-75^{\circ} \mathrm{C}$ and output of not less than $40{ }^{\circ} \mathrm{C}$, with a circulation time of at least 10 minutes. This was followed by an acidic detergent wash $(\mathrm{pH}<3)$ at a temperature of $30-35{ }^{\circ} \mathrm{C}$, and not exceeding $60{ }^{\circ} \mathrm{C}$, for 5 minutes. Before milking, a sanitizing solution with $25 \mathrm{ppm}$ iodine or $130 \mathrm{ppm}$ chlorine was applied 
for 5 minutes, at room temperature, without rinsing the equipment with water after use. Liners were exchanged every 6 months or every 2,500 milking, the hoses in direct contact with the milk were changed every 6 months, and the other hoses were changed annually. These changes were carried out in accordance with the regulations of the Brazilian Milk Quality Council (CBQL 2002).

For milk analysis, two to four samples of the cooling tank were collected monthly by the dairy company that buys the milk from the EETCG and sent for analysis to the Serviço de Análise de Rebanhos Leiteiros (SARLE) of the Universidade de Passo Fundo (UPF), certified by the Ministério da Agricultura, Pecuária e Abastecimento (MAPA) of Brazil. To determine amounts of the total dry extract (TDE), defatted dry extract (DDE), lactose, fat, and protein, the samples were analyzed by near-infrared Raman spectroscopy (NIRS, Bentley 2000, Bentley Instruments, USA) according to ISO 9622; somatic cell count (SCC) and total bacterial count (TBC) were determined using flow cytometry (Somacount 300, Bentley Instruments, USA), according to ISO 13366-2. Both methods are prescribed in INMETRO IEC 17025: 2002.

As the EETCG has a limit on the number of animals, some of the females (surplus heifers and discard cows) were sold and the milk equivalent production was calculated, i.e. the value received at the time of marketing of the animals was converted to liters of milk based on the average price received for milk in that month.

\section{STATISTICAL ANALYSIS}

The variables evaluated were: fat, protein, lactose, TDE, DDE, SCC, TBC, milk production, milk/ha, solids/ha, and milk equivalent. The seasons were classified as follows: 1 . Summer $=$ December, January, February; 2. Autumn $=$ March, April, May; 3. Winter = June, July, August; and 4. Spring $=$ September, October, November.
The SCC and TBC data were transformed as follows: (somatic cell score - $\mathrm{SCS}=\log 2(\mathrm{SCC} / 100)$ +3) (Ali and Shook 1980) and log 10 base (log10), respectively, since these variables did not present a normal distribution. The data were standardized using PROC STANDARD, standardizing averages $=0$ and variances $=1$, so that all variables contribute equally to the analysis, and precluding variables with larger numerical values being presented as being the most significant. Subsequently, the data were evaluated using multivariate analysis (factor and cluster) using $\mathrm{SAS} \circledast$ statistical software (SAS Institute 2002).

Factor analysis was used to evaluate the relationship between the variables to reduce the original set of variables to a smaller number of factors, and composing each factor with the variables that showed a relationship between them. Factor analysis was performed using PROC FACTOR, and KMO (Kaiser-Meyer-Olkin) statistics were used to verify the suitability of the model. The factorial loads (eigenvectors) were considered significant at a 0.40 cutoff, set with Promax rotation.

The cluster analysis was performed by creating groups of observations that show similarity within themselves and differences between the groups. For this, Ward's hierarchical method, based on Euclidean distance, was used to estimate the standardized means of the groups, and later they were transformed into the original means for each group.

The cluster analysis was complemented by Fisher's linear discriminant analysis (PROC DISCRIM), using the STPEDISC method to select the variables responsible for group differentiation. This was followed by canonical discriminant analysis (PROC CANDIS), used to graphically demonstrate the distances within and between groups. However, for these analyses, two important assumptions must be made: the assumption of a normal multivariate distribution and the assumption 
of multivariate homogeneity within covariance matrices.

Normal multivariate distribution was tested from the individual test of each response variable as there is no adequate test available for this assumption in most statistical software currently in use. Only the variable "season of the year" did not present a normal distribution. In contrast, the multivariate homogeneity test within covariance matrices, performed using the $\mathrm{POOL}=\mathrm{TEST}$ option in PROC DISCRIM, indicated the existence of homogeneity. Although the first assumption was not met, according to Manly (2004) if the great majority of the observations are correctly classified within the groups, Fisher's linear discriminant analysis can still be performed. In this case, all the observations were classified correctly within their groups according to the estimates of error count and, therefore, we continued with the discriminant analysis.

Finally, the means of the groups formed by the analysis of factors for each response variable were compared to verify which variables are responsible for the separation of the groups. For this, we tested the assumption of homogeneity of variances using Levene's test, normality of the errors using the Shapiro-Wilk's test, independence of the errors using the plot of residues against predicted values, and presence of outliers using box-plot graphs. All variables showed homogeneity of variances, but some showed non-normal errors and the presence of outliers. For this reason, nonparametric Kruskal-Wallis analysis using PROC NPAR1WAY was chosen, where the DSCF option was used to obtain the comparisons for the groups, considering that such analysis is based on the ranking of observations. In addition, the median was used as a measure of central tendency because it is not affected by extreme values. Results of all analyses were considered significant at $p<0.05$.

\section{RESULTS}

The operations listed in Figure 1 were planned and executed to produce quality milk without undesirable residues, and respecting the assumptions of sustainability, which should be socially just, economically viable and respectful of nature. It is important that Agricultural Technicians have a systemic view of the production chain. Therefore, managing sustainability influences the results presented below, as do the meteorological conditions (Table I) during the 4 years of evaluation. Table II shows the descriptive statistical analysis of all production parameters evaluated.

In the factorial analysis, milk composition, transformed SCC, and TBC could explain $75.9 \%$ of the total variance in the first three factors, with a KMO of 0.56 (Table III). The first factor represents the positive relationship between TDE, DDE, milk fat, and protein with the seasons. The second factor shows the positive relationship between milk production/hectare, lactose content, and the seasons. The third factor comprises the negative relationship of the lactose content with the transformed SCC and TBC, which is demonstrated by the opposition of its high factor loadings, where the increase in SCC and TBC reduces the milk lactose content. The high commonalities for all variables demonstrate their importance to study the relationship between milk production and composition with the seasons, health of the mammary gland, and milk microbiological quality.

In the canonical discriminant analysis, the difference between the groups formed by the cluster analysis was verified with the purpose of graphically showing the distances used in the separation between and within the groups (Figure 2). Within the cluster analysis, the discriminant analysis (Table IV) was performed using the STEPDISC method to select the variables that comprised the final model and that were determinants in the differentiation of the groups: TDE, followed by lactose content, 


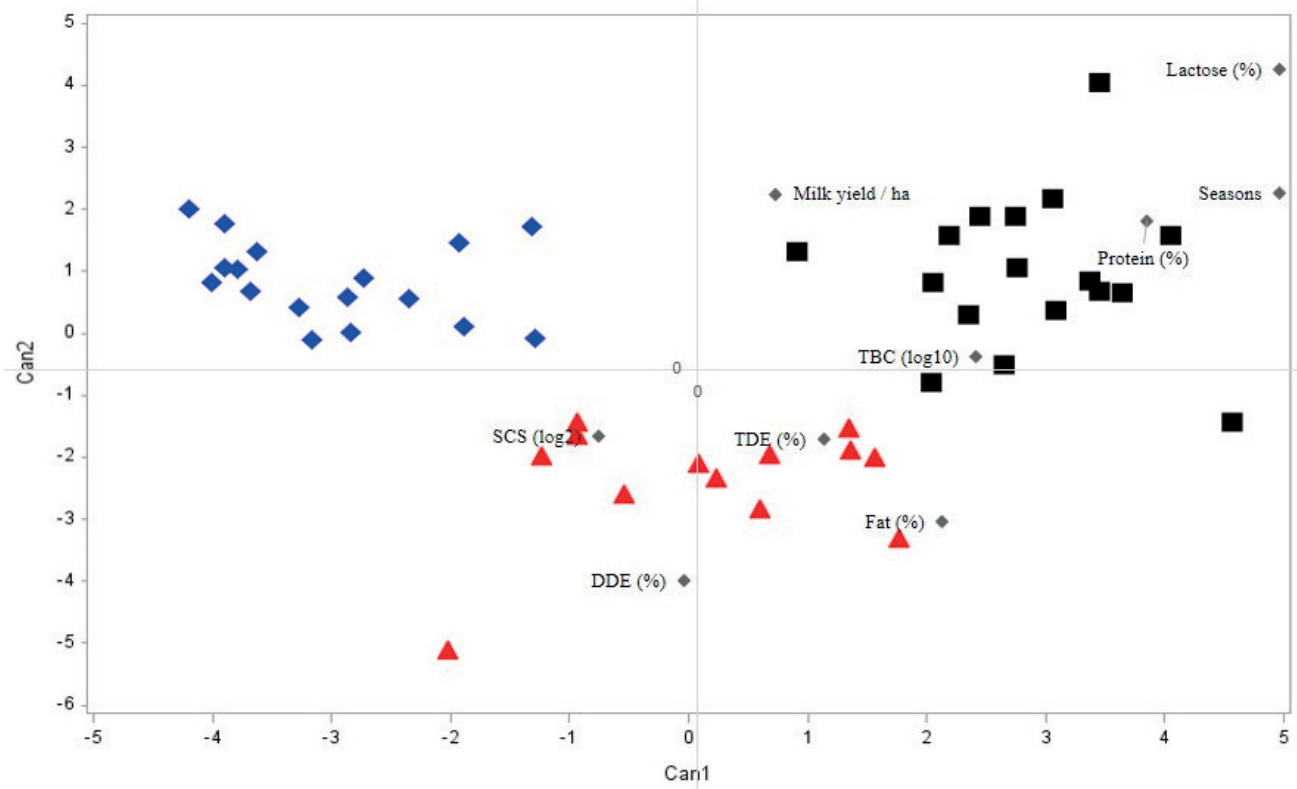

Figure 2 - Discriminant canonical analysis with monthly samples of milk production and composition according to the seasons, microbiological quality of milk and health of the mammary gland. Group 1 ( $\mathbf{\square})$; Group $2(\boldsymbol{\Delta})$; Group $3(\bullet)$.

TABLE II

Descriptive statistics of milk production and composition, somatic cell count and total bacterial count.

\begin{tabular}{|c|c|c|c|c|c|}
\hline \multirow{2}{*}{ Variables } & \multicolumn{5}{|c|}{ Descriptive statistics } \\
\hline & $\mathbf{N}$ & Minimum & Mean & Maximum & SE \\
\hline Milk production (L/ha·year) & 48 & $10.849,00$ & $16.785,01$ & $25.157,00$ & 511.04 \\
\hline Milk production $(\mathrm{L} /$ ha $\cdot$ month $)$ & 48 & 401.81 & 621.67 & 931.74 & 18.92 \\
\hline Milk equivalent (L) & 28 & 174.00 & 319.64 & 1.333 .61 & 70.25 \\
\hline Total solids (Kg/ha·month) & 47 & 46.14 & 95.49 & 219.64 & 6.18 \\
\hline Fat $(\%)$ & 48 & 2.95 & 3.36 & 3.66 & 0.02 \\
\hline Protein $(\%)$ & 48 & 2.77 & 3.03 & 3.31 & 0.01 \\
\hline Lactose $(\%)$ & 48 & 4.24 & 4.41 & 4.54 & 0.01 \\
\hline Dry defatted extract (\%) & 47 & 8.05 & 8.35 & 8.71 & 0.02 \\
\hline Total dry extract $(\%)$ & 47 & 11.13 & 11.71 & 12.14 & 0.03 \\
\hline $\mathrm{SCC}($ cells $/ \mathrm{mL} \times 1.000)$ & 48 & 93.33 & 271.36 & 598.00 & 16.32 \\
\hline $\mathrm{TBC}(\mathrm{CFU} / \mathrm{mL} \times 1.000)$ & 48 & 9.00 & 37.03 & 159.00 & 3.90 \\
\hline SCC transformed (SCS) & 48 & 4.97 & 5.39 & 5.78 & 0.02 \\
\hline TBC transformed $\left(\log _{10}\right)$ & 48 & 3.95 & 4.49 & 5.20 & 0.03 \\
\hline
\end{tabular}

$\mathrm{N}=$ number of observations; $\mathrm{SE}=$ standard error; $\mathrm{SCC}=$ somatic cell count; $\mathrm{SCS}=$ somatic cell score; $\mathrm{TBC}=$ total bacterial count. 
TABLE III

Factorial loadings, eigenvalue, percentage of variance and commonality of each variable that composes the factorial analysis of milk production and composition data according to the seasons of the year, microbiological quality of milk and health of the mammary gland.

\begin{tabular}{|c|c|c|c|c|}
\hline \multirow{2}{*}{ Variables } & \multicolumn{3}{|c|}{ Factors } & \multirow{2}{*}{ Communalities } \\
\hline & 1 & 2 & 3 & \\
\hline Season of the year ${ }^{1}$ & 0.401 & 0.351 & 0.288 & 0.401 \\
\hline Milk production (L/ha·year) & -0.176 & 0.913 & 0.194 & 0.839 \\
\hline Total dry extract (\%) & 0.953 & 0.081 & -0.073 & 0.963 \\
\hline Dry defatted extract (\%) & 0.820 & 0.344 & 0.014 & 0.902 \\
\hline Fat $(\%)$ & 0.835 & -0.217 & -0.139 & 0.738 \\
\hline Protein $(\%)$ & 0.863 & -0.129 & 0.248 & 0.689 \\
\hline Lactose $(\%)$ & 0.151 & 0.766 & -0.407 & 0.840 \\
\hline SCC transformed (SCS) & -0.179 & 0.101 & 0.854 & 0.789 \\
\hline TBC transformed $\left(\log _{10}\right)$ & 0.269 & -0.066 & 0.787 & 0.652 \\
\hline Variance explained (\%) & 39.7 & 18.9 & 17.3 & \\
\hline
\end{tabular}

${ }^{1}$ Season $=1$ : Summer $=$ December, January, February; 2: Fall = March, April, May; 3: Winter $=$ June, July, August; 4: Spring = September, October, November. Seasons according to the Southern Hemisphere. SCC = somatic cell count; SCS = somatic cell score; $\mathrm{TBC}=$ total bacterial count.

seasons of the year, milk production per hectare, and protein content.

Groups 1 and 3 did not differ in monthly milk production, but presented a difference for season of the year, fat, protein, and lactose contents. These affected the TDE and DDE, where group 1 was represented by milk produced in the spring, having a higher total solid content and consequently ESD, followed by the best milk composition represented by fat, protein, and lactose content, compared to group 3 (Table V). Groups 2 and 3 represented milk produced in the autumn, with group 2 being characterized by lower milk yield and higher TDE due to higher fat and protein content, which are the same as in group 1. The DDE differed in the three groups, with group 3 presenting the lowest value due to the reduction in protein and lactose contents. The three groups showed no difference in SCS and TBC.

\section{DISCUSSION}

As the feed base of milk cows in Brazil is pasture, one index that can facilitate the evaluation of the efficiency of milk production is the milk yield per hectare (Table II). The average productivity of the DCEU shows that with the use of high quality preserved feeds and pastures, satisfactory rates (621.67 liters/ha'month) were obtained and the microbiological quality represented by SCC and TBC was excellent, with average values of $271,360 \mathrm{cells} / \mathrm{mL}$ and $37,030 \mathrm{cfu} / \mathrm{mL}$, respectively. The quality of the milk produced complies with the Brazilian legislation that will come into force in 2018 , which is 400,000 cells $/ \mathrm{mL}$ for SCC and $100,000 \mathrm{cfu} / \mathrm{mL}$ for TBC for the southern, southeastern and central-west regions according to the IN 62 of MAPA (Brasil 2011).

The results of milk quality are influenced by the health of the animals as well as by the hygiene in the milking processes. The factors that determine milk production are interactive. Feeding and nutrition of the herd was managed so that the body condition scores were not less than 3 , according to the scale of the NRC (2001).

The positive relationship between the season and the whole composition of milk can be observed 
in the comparisons between groups (Table V). From this, it is possible to infer that milk produced in the spring has higher levels of fat, protein, and lactose and, consequently, higher TDE and DDE, which can be explained by the milder temperatures and by the availability and better quality of temperate forages, which favors the consumption of dry matter. Noro et al. (2006) and Heck et al. (2009) reported that the higher yields and better composition of milk produced in winter and spring is related to the quantity and quality of temperate forage. The intake of feed by lactating cows is influenced by availability (Mühlbach 2010) and animal nutrient demand, as well as by digestive kinetics (Kammes and Allen 2012), all of which affect milk production (Linton and Allen 2009); they affect the availability of metabolites for the synthesis of milk components, and consumption is directly related to milk production (Bjerre-Harpøth et al. 2012).

The relationship of the season with milk production per hectare and lactose content is also clear in the groups (Table V). In semi-confinement systems, the season of the year is one of the factors that could affect lactose content of milk and, consequently, the production of milk. Lactose, the main carbohydrate in milk, is synthesized principally from glucose (Lemosquet et al. 2009); production of glucose begins with fermentation of most non-fibrous carbohydrates (NFC) in the rumen, which produces propionic acid that is absorbed and metabolized to glucose in the liver; glucose is subsequently used in the synthesis of lactose, the main determinant of milk production (Allen and Piantoni 2014).

Therefore, the synthesis of lactose is highly dependent on the energy status of the cows, which in turn is directly related to feed intake. Mainly in the spring, but also in the winter, the quantity and nutritional quality of the milk is higher when compared to summer pasture (Noro et al. 2006), due to the use of oats (Avena sp.) and ryegrass
(Lolium multiflorum). Together with the feed and concentrate supplied in the trough, they can meet the nutritional requirements of lactating cows without compromising milk production and/or altering milk composition.

In general, lactose content is negatively affected by SCC and TBC (Alessio et al. 2016), but this relationship was not observed in the cluster analysis, since SCC and TBC did not show differences between the groups (Table V). However, the negative relationship between SCC and lactose content was evident in a multivariate analysis of dairy control data (Alessio et al. 2016). The SCC and TBC have a negative effect on lactose content when lactose is used as a substrate for the development and growth of the bacteria present in the milk (Blum et al. 2008, Silanikove et al. 2014). Moreover, mastitis may reduce lactose secretion in mammary gland epithelial cells (Moussaoui et al. 2004, Silanikove et al. 2009) and increase the permeability of tight junctions between alveolar epithelial cells, resulting in loss of lactose into the bloodstream (Moussaoui et al. 2004, Pessoa et al. 2012).

Another factor that may contribute to explaining the variation in monthly milk production and lactose content related to the seasons is the heat stress that affects lactating cows in the summer and fall. In semi-confinement systems, heat stress can be aggravated by the scarcity of pasture at the end of the vegetative stage. Heat stress has become one of the most important challenges for the milk production chain, since it affects the health, reproduction, behavior, and biological activity of lactating cows, due to a reduction in voluntary consumption and consequent reduction in nutrient availability (Polsky and Von Keyserlingk 2017, Rhoads et al. 2009). Heat stress may also be related to the reduction in milk protein and lactose content, since it increases systemic use of amino acids and limits the supply of amino acids and glucose to the mammary gland. In addition, increased amino 
TABLE IV

Discriminant analysis of the determinant variables for differentiation of the groups and their respective statistical parameters of milk production and composition data according to the seasons of the year, microbiological quality of milk, and health of the mammary gland.

\begin{tabular}{lccccccc}
\hline \multicolumn{1}{c}{ Variables } & Partial R & F & P $<$ F & WL $^{\mathbf{1}}$ & $\begin{array}{c}\mathbf{P}< \\
\text { Lambda }\end{array}$ & ASCC $^{2}$ & P $<$ ASCC \\
\hline Total dry extract (\%) & 0.786 & 80.96 & $<0.0001$ & 0.213 & $<0.0001$ & 0.393 & $<0.0001$ \\
Lactose (\%) & 0.413 & 15.15 & $<0.0001$ & 0.125 & $<0.0001$ & 0.597 & $<0.0001$ \\
Season of the year (month) & 0.529 & 23.67 & $<0.0001$ & 0.058 & $<0.0001$ & 0.736 & $<0.0001$ \\
Milk production (kg/ha) & 0.108 & 2.50 & 0.094 & 0.052 & $<0.0001$ & 0.756 & $<0.0001$ \\
Protein (\%) & 0.109 & 2.47 & 0.097 & 0.046 & $<0.0001$ & 0.768 & $<0.0001$ \\
\hline
\end{tabular}

${ }^{1}$ Wilks Lambda; ${ }^{2}$ Average Squared Canonical Correlation.

TABLE V

Comparison of medians using Kruskal-Wallis test for the groups formed according to the production and composition of the milk for the seasons of the year, microbiological quality of the milk, and the health of the mammary gland.

\begin{tabular}{|c|c|c|c|c|}
\hline \multirow{2}{*}{ Variables } & \multicolumn{3}{|c|}{ Groups } & \multirow{2}{*}{$\mathbf{P}$} \\
\hline & 1 & 2 & 3 & \\
\hline Season of the year (month) ${ }^{1}$ & $4.00^{\mathrm{a}}$ & $2.00^{\mathrm{b}}$ & $2.00^{\mathrm{b}}$ & $<0.0001$ \\
\hline Milk production $(\mathrm{L} / \mathrm{ha} \cdot \mathrm{month})$ & $679.63^{\mathrm{a}}$ & $517.57^{\mathrm{b}}$ & $607.17^{\mathrm{a}}$ & $=0.0005$ \\
\hline Total dry extract (\%) & $11.90^{\mathrm{a}}$ & $11.89^{\mathrm{a}}$ & $11.40^{\mathrm{b}}$ & $<0.0001$ \\
\hline Dry defatted extract (\%) & $8.50^{\mathrm{a}}$ & $8.40^{\mathrm{b}}$ & $8.19^{\mathrm{c}}$ & $<0.0001$ \\
\hline Fat $(\%)$ & $3.43^{\mathrm{a}}$ & $3.53^{\mathrm{a}}$ & $3.21^{\mathrm{b}}$ & $<0.0001$ \\
\hline Protein $(\%)$ & $3.09^{\mathrm{a}}$ & $3.11^{\mathrm{a}}$ & $2.95^{\mathrm{b}}$ & $<0.0001$ \\
\hline Lactose (\%) & $4.47^{\mathrm{a}}$ & $4.39^{\mathrm{b}}$ & $4.38^{\mathrm{b}}$ & $<0.0001$ \\
\hline SCC transformed (SCS) & 5.40 & 5.36 & 5.40 & $<0.5538$ \\
\hline TBC transformed $\left(\log _{10}\right)$ & 4.53 & 4.48 & 4.35 & $=0.1010$ \\
\hline Number of observations & 17 & 13 & 18 & \\
\hline
\end{tabular}

${ }^{1}$ Season $=1$ : Summer $=$ December, January, February; 2: Fall = March, April, May; 3: Winter $=$ June, July, August; 4: Spring = September, October, November. Seasons according to the Southern Hemisphere. SCC = somatic cell count; SCS = somatic cell score TBC $=$ total bacterial count; ${ }^{\text {abc }}=$ different superscript letters indicate a significant difference between medians.

acid requirements during heat stress may represent an increased need for gluconeogenic precursors (Gao et al. 2017). In dairy cows under heat stress, a reduction of 200 to $400 \mathrm{~g}$ of lactose produced daily is observed, with glucose being consumed at a higher rate (Wheelock et al. 2010). In these conditions, there is an increase in glycolysis and anaerobic respiration to maintain energy balance (Tian et al. 2015), and the decrease in glycemia may explain the reduction of lactose content (Shwartz et al. 2009). Accordingly, changes in protein and lactose levels may be related to a reduction in feed intake by dairy cows under thermal stress (Polsky and Von Keyserlingk 2017, Rhoads et al. 2009).
In general, the Brazilian dairy industry has routinely received milk with TDEs similar to, or smaller than, those seen in Group 3 (Table V), which has generated major concerns due to the negative impact on dairy product yields; this is the case with milk powder, which, according to Pinha et al. (2016), is the second most globally traded dairy derivative. In the specific cases of low lactose $(4.38 \%)$ and low protein (2.94\%), Leitner et al. (2011) have suggested that these may affect milk coagulation, thus reducing industrial yield in cheese production. In a study carried out in Brazil, Martins et al. (2006) observed that in $65 \%$ of the 1,753 milk samples used in the study, the DDE content 
was below $8.4 \%$, which is the minimum value determined by Normative Instruction 62 (Brasil 2011); for protein content, the percentage below the minimum (2.9\%) was $35 \%$. Therefore, the low DDE content may be related to the low lactose content of $4.3 \%$ stipulated by the Regulamento de Inspeção Industrial e Sanitária de Produtos de Origem Animal Industrial-RIISPOA (Brasil 1952, 2017).

Milk production and composition vary over the years, mainly due to the seasons, which is characteristic of systems based on pasture production. Variations in the composition of the main components of milk, such as lactose, fat, and protein, affect production of total solids. There is still a need to reduce the somatic cell count of the milk produced.

Based on the results obtained in the present study, it is clear that farm management affects production, composition, and quality of the milk. However, as many factors are involved in the production system, multivariate analyses enabled us to identify the main factors that can affect and explain the variation within the productive system. Based on these findings, farmers should consider all the factors together, and not in isolation when an evaluation of their dairy system is required. Finally, we emphasize that medium and long-term studies using multivariate analysis are of fundamental importance for knowledge and the improvement of the milk production chain in Brazil.

\section{CONCLUSIONS}

Using multivariate analyses, we were able to understand, as a whole, the relationship between milk production and composition in the studied farm. Three factors were found to influence the system: factor 1 represented the positive relationship between seasons (spring and winter), TDE, DDE, fat, and protein content; factor 2 represented the positive relationship between lactose content, milk production/ha, and seasons (spring and winter); and factor 3 represented the negative relationship between lactose content with SCC and TBC. From these factors, three groups of observations were formed, where TDE, lactose content, protein content, seasons, and milk production/ha were the variables responsible for the formation and separation of the groups of observations.

\section{ACKNOWLEDGMENTS}

We thank the Ministério da Agricultura, Pecuária e Abastecimento (MAPA) and the Instituto Nacional de Meteorologia (INMET) for the provision of meteorological data. This study was financed in part by the Coordenação de Aperfeiçoamento de Pessoal de Nível Superior (CAPES) - Finance Code 001, with the scholarship to Marcos Busanello in the Doctor degree course in Animal Science and Pastures (ESALQ - USP) and with the scholarship to Micheli Regiani Sippert in the Master degree course in Animal Science - UEM.

\section{REFERENCES}

ALESSIO DRM, THALER NETO A, VELHO JP, PEREIRA IB, MIQUELLUTI DJ, KNOB DA AND DA SILVA ECG. 2016. Multivariate analysis of lactose content in milk of Holstein and Jersey cows. Sem Cienc Agrar 37: 26412652.

ALIAKAAND SHOOK GE. 1980. An optimum transformation for somatic cell concentration in milk. J Dairy Sci 63: $487-$ 490.

ALLEN MS AND PIANTONI P. 2014. Carbohydrate Nutrition: Managing energy intake and partitioning through lactation. Vet Cli Food Anim 30: 577-597.

ALVARES CA, STAPE JL, SENTELHAS PC, GONÇALVES JLM AND SPAROVEK G. 2013. Köppen's climate classification map for Brazil. Meteorol Z 22: 711-728.

ARYANA KJ AND OLSON DW. 2017. A 100-year review: Yogurt and other cultured dairy products. J Dairy Sci 100: 9987-10013.

BARGO F, MULLER LD, DELAHOY JE AND CASSIDY TW. 2002. Performance of high producing dairy cows with three different feeding systems combining pasture and total mixed rations. J Dairy Sci 85: 2948-2963.

BJERRE-HARPØTH V, FRIGGENS NC, THORUP VM, LARSEN T, DAMGAARD BM, INGVARTSEN KL AND 
MOYES KM. 2012. Metabolic and production profiles of dairy cows in response to decreased nutrient density to increase physiological imbalance at different stages of lactation. J Dairy Sci 95: 2362-2380.

BLUM S, HELLER ED, KRIFUCKS O, SELA S, HAMMERMUNTZ O AND LEITNER G. 2008. Identification of a bovine mastitis Escherichia coli subset. Vet Microbiol 132: 135-148.

BRASIL. 1952. Decreto 30.691/1952. Regulamento de Inspeção Industrial e Sanitária de Produtos de Origem Animal (RIISPOA). Ministério da Agricultura, Pecuária e Abastecimento. Brasília: Diário Oficial da União 1: 10785.

BRASIL. 2002. Instrução Normativa $n^{\circ} 51$, de 20 de setembro de 2002. Brasília: Diário Oficial da União 1: 13.

BRASIL. 2011. Instrução Normativa ${ }^{\circ}$ 62, de 30 de dezembro de 2011. Brasília: Diário Ofícial da União 1: 8-10.

BRASIL. 2017. Inspeção Industrial e Sanitária de Produtos de Origem Animal, Decreto No 9.013 de 29 de março de 2017. Aprova o novo regulamento da inspeção industrial e sanitária de produtos de origem animal. Brasília: Diário Oficial da União 1: 41.

CBQL - CONSELHO BRASILEIRO DE QUALIDADE DO LEITE. 2002. Comitê de Equipamentos. Equipamentos de ordenha: recomendações do Comitê de Equipamentos CBQL - São Paulo: Quiron, 28 p.

CHARLEBOIS S AND HARATIFAR S. 2015. The perceived value of dairy product traceability in modern society: An exploratory study. J Dairy Sci 98: 3514-3525.

DALL-ORSOLETTA AC, ALMEIDA JGR, CARVALHO PCF, SAVIAN JV AND RIBEIRO-FILHO HMN. 2016. Ryegrass pasture combined with partial total mixed ration reduces enteric methane emissions and maintains the performance of dairy cows during mid to late lactation. J Dairy Sci 99: 4374-4383.

FAGAN EP, JOBIM CC, CALIXTO JÚNIOR M, SILVA MS AND DOS SANTOS GT. 2010. Fatores ambientais e de manejo sobre a composição química do leite em granjas leiteiras do Estado do Paraná, Brasil. Acta Sci Anim Sci 32: 309-316.

FOX DG, TEDESCHI LO, TYLUTKI TP, RUSSELL JB, VAN AMBURGH ME, CHASE LE, PELL AN AND OVERTON TR. 2004. The Cornell Net Carbohydrate and Protein System model for evaluating herd nutrition and nutrient excretion. Anim Feed Sci Technol 112: 29-78.

GANCHE E, DELABY L, O’DONOVAN M, BOLAND TM AND KENNEDY E. 2014. Short-term response in milk production, dry matter intake, and grazing behavior of dairy cows to changes in postgrazing sward height. J Dairy Sci 97: 3028-3041.

GAO ST, GUO J, QUAN SY, NAN XM, FERNANDEZ MVS, BAUMGARD LH AND BU DP. 2017. The effects of heat stress on protein metabolism in lactating Holstein cows. J Dairy Sci 100: 5040-5049.
HECK JML, VAN VALENBERG HJF, DIJKSTRA J AND VAN HOOIJDONK ACM. 2009. Seasonal variation in the Dutch bovine raw milk composition. J Dairy Sci 92: 47454755.

HRISTOV AN, PRICE WJ AND SHAFII B. 2005. A metaanalysis on the relationship between intake of nutrients and body weight with milk volume and milk protein yield in dairy cows. J Dairy Sci 88: 2860-2869.

JENKINS TC AND MCGUIRE MA. 2006. Major advances in Nutrition: Impact on milk composition. J Dairy Sci 89: 1302-1310.

KAMMES KL AND ALLEN MS. 2012. Nutrient demand interacts with forage family to affect digestion responses in dairy cows. J Dairy Sci 95: 3269-3287.

LANZAS C, SNIFFEN CJ, SEOA S, TEDESCHI LO AND FOX DG. 2007. A revised CNCPS feed carbohydrate fractionation scheme for formulating rations for ruminants. Anim Feed Sci Technol 136: 167-190.

LEBART L, MORINEAU AAND PIRON M. 2000. Statistique exploratoire multidimensionnelle, $3^{\text {rd }}$ ed., Paris: Dunod, $456 \mathrm{p}$.

LEITNER G, MERIN U AND SILANIKOVE N. 2011. Effects of glandular bacterial infection and stage of lactation on milk clotting parameters: Comparison among cows, goats and sheep. Int Dairy J 21: 279-285.

LEMOSQUET S, DELAMAIRE E AND LAPIERRE H. 2009. Effects of glucose, propionic acid and nonessential amino acids on glucose metabolism and milk yield in Holstein dairy cows. J Dairy Sci 92: 3244-3257.

LINTON JV AND ALLEN MS. 2009. Nutrient demand interacts with forage family to affect nitrogen digestion and utilization responses in dairy cows. J Dairy Sci 92: 1594-1602.

MACDONALD KA, PENNO JW, LANCASTER JAS, BRYANT AM, KIDD JM AND ROCHE JR. 2017. Production and economic responses to intensification of pasture-based dairy production systems. J Dairy Sci 100: 6602-6619.

MANLY BFJ. 2004. Multivariate statistical methods: A primer, $3^{\text {rd }}$ ed., London: Chapman and Hall, 209 p.

MARTINS PRG, DA SILVA CA, FISCHER V, RIBEIRO MEE, JÚNIOR WS AND ZANELA MB. 2006. Produção e qualidade do leite na bacia leiteira de Pelotas - RS em diferentes meses do ano. Ciênc Rural 36: 209-214.

MELE M, MACCIOTTA NPP, CECCHINATO A, CONTE G, SCHIAVON S AND BITTANTE G. 2016. Multivariate factor analysis of detailed milk fatty acid profile: Effects of dairy system, feeding, herd, parity, and stage of lactation. J Dairy Sci 99: 9820-9833.

MOUSSAOUI F, VANGROENWEGHE F, HADDADI K, LE ROUX Y, LAURENT F, DUCHATEAU L AND BURVENICH C. 2004. Proteolysis in milk during 
experimental Escherichia coli mastitis. J Dairy Sci 87: 2923-2931.

MÜHLBACH PRF. 2010. Considerações sobre a otimização do consumo da vaca leiteira. In: Vieira SL (Ed), Consumo e preferência alimentar dos animais domésticos, Londrina, Phytobiotics Brasil, Londrina, Brasil, p. 100-152.

NRC - NATIONAL RESEARCH COUNCIL. 2001. Nutrient Requirements of Dairy Cattle, $7^{\text {th }}$ ed., Washington: National Academies Press, $408 \mathrm{p}$.

NORO G, GONZÁLEZ FHD, CAMPOS R AND DURR JW. 2006. Fatores ambientais que afetam a produção e a composição do leite em rebanhos assistidos por cooperativas no Rio Grande do Sul. Rev Bras Zootec 35: 1129-1135.

PÉREZ-PRIETO LA AND DELAGARDE R. 2012. Metaanalysis of the effect of pregrazing pasture mass on pasture intake, milk production, and grazing behavior of dairy cows strip-grazing temperate grasslands. J Dairy Sci 95: 5317-5330.

PÉREZ-PRIETO LA AND DELAGARDE R. 2013. Metaanalysis of the effect of pasture allowance on pasture intake, milk production, and grazing behavior of dairy cows grazing temperate grasslands. J Dairy Sci 96: 66716689.

PESSOA RB, BLAGITZ MG, BATISTA CF, SANTOS BP, PARRA AC, SOUZA FN AND DELLA LIBERA AMMP. 2012. Avaliação da apoptose de leucócitos polimorfonucleares $\mathrm{CH} 138+$ em leite bovino de alta e baixa contagem de células somáticas dados preliminares. Arq Bras Med Vet Zootec 64: 533-539.

PETIT HV. 2009. Antioxidants and dairy production: the example of flax. Rev Bras Zootec 38: 352-361.

PINHA LC, BRAGA MB AND CAMPOS AC. 2016. Grau de concorrência e poder de mercado nas exportações de leite em pó para o Brasil. Rev Econ Sociol Rural 54: 393-412.

POLSKY L AND VON KEYSERLINGK MAG. 2017. Invited review: Effects of heat stress on dairy cattle welfare. J Dairy Sci 100: 1-13.

RHOADS ML, RHOADS RP, VANBAALE MJ, COLLIER RJ, SANDERS SR, WEBER WJ, CROOKER BA AND BAUMGARD LH. 2009. Effects of heat stress and plane of nutrition on lactating Holstein cows: I. Production, metabolism, and aspects of circulating somatotropin. J Dairy Sci 92: 1986-1997.

SAINZ-SÁNCHEZ PA, LÓPEZ-GONZÁLEZ F, ESTRADAFLORES JG, MARTÍNEZ-GARCÍA CG AND ARRIAGA-JORDÁN CM. 2017. Effect of stocking rate and supplementation on performance of dairy cows grazing native grassland in small-scale systems in the highlands of central Mexico. Trop Anim Health Prod 49: 179-186.

SAS INSTITUTE. 2002. SAS/STAT. Guide for personal computers. Cary, v.1.
SHWARTZ G, RHOADS ML, VAN BAALE MJ, RHOADS RP AND BAUMGARD LH. 2009. Effects of a supplemental yeast culture on heat-stressed lactating Holstein cows. J Dairy Sci 92: 935-942.

SILANIKOVE N, MERIN U, SHAPIRO F AND LEITNER G. 2014. Milk metabolites as indicators of mammary gland function sand milk quality. J Dairy Res 81: 358-363.

SILANIKOVE N, SHAPIRO F AND SHINDER D. 2009. Acute heat stress brings down milk secretion in dairy cows by up-regulating the activity of the milk-borne negative feedback regulatory system. BMC Physiol 9: 13.

SMID AMC, WEARY DM, COSTA JHC AND VON KEYSERLINGK MAG. 2018. Dairy cow preference for different types of outdoor access. J Dairy Sci 101: 14481455.

TAMBARA AAC, SIPPERT MR, JAURIS GC, FLORES JLC, HENZ ELH AND VELHO JP. 2017. Production and chemical composition of grasses and legumes cultivated in pure form, mixed or in consortium. Acta Sci Anim Sci 39: 235-241.

TIAN H, WANGB W, ZHENGA N, CHENGC J, LIA S, ZHANGA Y AND WANGA J. 2015. Identification of diagnostic biomarkers and metabolic pathway shifts of heat-stressed lactating dairy cows. J Proteomics 125: 1728.

TODDE G, MURGIA L, CARIA M AND PAZZONA A. 2016. A multivariate statistical analysis approach to characterize mechanization, structural and energy profile in Italian dairy farms. Energy Reports 2: 129-134.

TYLUTKI TP, FOX DG, DURBAL VM, TEDESCHI LO, RUSSELL JB, VAN AMBURGH ME, OVERTON TR, CHASE LE AND PELL AN. 2008. Cornell Net Carbohydrate and Protein System: A model for precision feeding of dairy cattle. Anim Feed Sci Technol 143: 174202.

VAN SOEST PJ. 1994. Nutritional ecology of the ruminant. Ithaca: Cornell University Press, $476 \mathrm{p}$.

VIRBAT RE, TAVENDALE M, OTTER D, SCHWENDEL BH, LOWE K, GREGORINI P AND PACHECO D. 2017. Milk production and composition, nitrogen utilization, and grazing behavior of late-lactation dairy cows as affected by time of allocation of a fresh strip of pasture. J Dairy Sci 100: 5305-5318.

VON KEYSERLINGK MAG, RUSHEN J, DE PASSILLÉ AM AND WEARY DM. 2009. Invited review: The welfare of dairy cattle - Key concepts and the role of science. J Dairy Sci 92: 4101-4111.

WHEELOCK JB, RHOADS RP, VANBAALE MJ, SANDERS SR AND BAUMGARD LH. 2010. Effects of heat stress on energetic metabolism in lactating Holstein cows. J Dairy Sci 3: 644-655. 